\title{
Are You Oil or Sand? Resolving Conflict in Christian Global Healthcare
}

\author{
David L. Stevens ${ }^{a}$
}

a MD, MA(Ethics), CEO, Christian Medical and Dental Associations, USA

Before we left for our first term of service in Kenya in 1981, a former missionary gave me some sage advice. He said, "David, one of the greatest blessings you will have in missionary services will be through the deep relationships you develop with your fellow missionaries and national colleagues. It is just as true that your greatest conflicts will come because of your relationships with your fellow missionaries and national colleagues!"

I soon found that both assertions were true. In Christian global healthcare, you usually don't get to pick your friends. You live, work, play and worship with a group chosen for you by others in a pressure cooker environment of too much work, too few resources and profound interdependence. It is a recipe for problems. It is no wonder the most common reason, in my experience, that Christian healthcare professionals return to their home countries is interpersonal conflict.

Add to that the significant cultural difference between expatriate staff from different countries and national staff from different tribal or ethnic groups, and there is more potential conflict poured into the pot due to varying worldviews or long term prejudices.

During my language training, a man from the tribal group we worked with made a disparaging remark about someone from an adjacent tribe. When I asked why, he immediately responded, "They're black! They eat fish! Their men are uncircumcised. There is nothing worse than being uncircumcised." I naively respond- ed, "But you have dark skin." He retorted, "But he is really black!"

And this pressure cooker is often placed inside a larger pressure chamber of political differences, economic tensions, religious extremism, corruption, crime and even armed conflict. Almost all Christians serving in global healthcare are providing care in the midst of some level of conflict. Conflict at the interpersonal level ultimately impacts the effectiveness of teams, organizations, institutions, governments and nations.

Remember that there are only two kinds of conflict. The first is the type you can help prevent and often resolve within your community. The second is the type you can only hope to ameliorate and is often due to ethnic, tribal, religious or political struggles.

As I help train new healthcare missionaries to deal with conflict, I draw upon the excellent principles taught in The Peacemaker: A Biblical Guide to Resolving Personal Conflict by Ken Sande. ${ }^{1}$ The book is an excellent source reminding us that it is each Christian's responsibility to be a "peacemaker" rather than a "peace taker." We should not cause, endure or ignore conflict. As James 1:2-4 reminds us, God uses conflict to reveal, exercise, mature and strengthen our faith.

Almost all conflict is caused by our unmet expectations and desires to have our own way. Because of that, my first obligation in a conflict is to examine myself.

May 2015. Christian Journal for Global Health 2(1):3-6. 
What causes fights and quarrels among you? Don't they come from your desires that battle within you? You want something but don't get it. (James 4:1-2). ${ }^{2}$

Resolving conflict starts with allowing the Great Physician to do a personal heart exam and then therapy. His intention for us is clear:

I'm telling you to love your enemies.

Let them bring out the best in you, not the worst. When someone gives you a hard time, respond with the energies of prayer, for then you are working out of your true selves, your Godcreated selves. (Matthew 5:44-45). ${ }^{3}$

You first need to let God work in you to cleanse your heart of anger and selfish motives and then give you a genuine love for the person with whom you have a conflict. Dr. Ernie Steury, the founder of Tenwek Hospital in Kenya, was my mentor for many years. I remember one situation when he was dealing with another senior missionary who had caused many problems and publicly attacked him. "He had every reason to be angry and upset, but he wasn't. He told me why. He said, 'Dave, I've learned if I genuinely pray for God's best for the person I'm having a problem with, it changes my attitude towards them. I don't ask for God to change them. I ask God to overflow my heart with love for them." 4

Luke, the physician, quoted Christ who summed up what we should do in the midst of conflict, "...Love your enemies, do good to those who hate you, bless those who curse you, pray for those who mistreat you" (Luke 6:2728). ${ }^{3}$ Global health workers involved in conflict often think they are doing well if they just tolerate the other person, but God set a much higher standard in His demand for genuine love, and $\mathrm{He}$ is the one who enables each person to do it.

In situations of conflict, people often interpret every action, word and even the body language of the person they are upset with in the worst light. They are eager to add fuel to the fire of their anger to justify their thoughts and actions. Christ tells us we are not to do that, even when the other person is at fault or has failed. The Message puts it into clear everyday language and says, "Don't pick on people, jump on their failures, criticize their faults-unless, of course, you want the same treatment" (Luke 7:1-2). ${ }^{3}$

After these steps, it is time for some successful soul surgery by the Great Physician. Even before we try to deal with the conflict or they ask for forgiveness, we are to unconditionally forgive the person who wronged us. It is not easy, but it is necessary, to have our heart empty of malice, resentment and the desire to triumph in the situation. Just as God forgave us, we are to forgive those who have offended us (Colossians 3:13, Galatians 6:1). ${ }^{3}$ We didn't deserve His forgiveness, but He freely forgave our sins by paying the price for them. If you are struggling with this step of dealing with your anger, bitterness or rage, find a friend with whom you can be completely honest. Don't focus on the person with whom you are having the conflict; instead, honestly share your own heart. Saying how you feel out loud often has a therapeutic effect. Add prayer and God can flood your heart with forgiveness.

As Ken Sande recommends, honestly ask yourself, "Is the offense seriously dishonoring God? Has it permanently damaged a relationship? Is it seriously hurting other people? Is it seriously hurting the offender himself?" If you can answer in the negative to each of these questions, let the problem roll off your back like water off a duck! Forgive and forget.

If you answer "Yes" to any of these questions, you need to deal with the conflict in the right way. Your goal should be restoration. Pursue that with gentleness, mercy and good intent by approaching the issue in a winsome way. You want to renew and even strengthen 
your relationship. If you meet with the person intending to show them they are wrong, there is little chance that true restoration will take place.

Commit the approaching conversation to prayer, asking God to give you wisdom, grace and humility. You want to communicate in a spirit of love and that is not easy, but we are given an example on how to proceed as the apostle Paul writes in Ephesians 6:19-20, "And don't forget to pray for me. Pray that I'll know what to say and have the courage to say it at the right time...." In extremely difficult situations, you may want to rehearse what you plan to say and even ask a trusted friend to critique it to ensure you are using the right strategy, the right words and even the right tone. If you were on the other end of the conversation, ask yourself what would you want the other person to say to you and how.

It is now time to ask to meet, and it is often best to do that in a neutral place with few distractions, interruptions and people to overhear. You do not want either person to feel trapped or be distracted. You may want to ask if you can meet for a cup of coffee or tea because you want to talk to them about something. Then work to relax and find peace in your heart. You have done all the hard work and the result is not dependent on you but on your Heavenly Father. God expects us to obey His admonishing to deal with conflict and then promises to be with us as we do.

If you don't get to a resolution and the problem is serious, the next thing is to follow the guidance in Matthew 18:16 that says, "If he won't listen, take one or two others along so that the presence of witnesses will keep things honest, and try again." ${ }^{3}$ That person may be a senior missionary or a national leader who is trusted by both people in conflict.

In a situation where you are still unsuccessful - and sometimes you will be - rest in the fact that you have done your part to make things right. Continue to pray for the other person and work to love them.

In the community health work I started in Kenya, our slogan was "Bir Mat Ko Lo!" It is an old Kipsigis proverb that admonishes to "Beat the Fire While it is Far" if you want to avoid your house or livestock being consumed by fire. With good training and leadership, you can beat the fire of conflict before it becomes a forest fire. Leaders need to recognize smoldering conflict and get involved early. They also need to avoid the trap of ignoring conflict out of fear that trying to solve it will make matters worse and someone will get mad and leave the organization. As leaders, they need to hold those they lead accountable to resolving disputes and then assisting them as a mediator when necessary.

Conflict is inevitable and is only exacerbated by the parameters of missionary service and the stresses of healthcare globally. The bottom line is: are we going to be the oil in the gears among your colleagues or the sand? Are we going to prevent and solve conflicts or be the cause of them? The goal is productive, cooperative and sustainable work leading to widespread healing impact and witness. God is clear in His instructions to promote peace and vitality. We just need to follow them.

\section{References}

1. Sande K. The peacemaker: a biblical guide to resolving personal conflict. $3^{\text {rd }}$ ed. Grand Rapids: Baker Books; 2004.

2. The Bible, New International Version. Grand Rapids: Zondervan; 1984.

3. Peterson EH. The message: the Bible in contemporary language. Version 2.0. Colorado Springs: NavPress; 2002.

4. Stevens DL. Beyond medicine: what else you need to know to be a medical missionary. Bristol: Christian Medical \& Dental Associations, 2013. 
Competing Interests: None declared.

Correspondence: Dr. David Stevens, Christian Medical and Dental Associations, Bristol, TN, USA executive@cmda.org

Cite this article as: Stevens DL. Are you oil or sand? Resolving conflict in Christian global healthcare. Christian Journal for Global Health (May 2015), 2(1):3-6.

(C) Stevens, DL. This is an open-access article distributed under the terms of the Creative Commons Attribution License, which permits unrestricted use, distribution, and reproduction in any medium, provided the original author and source are properly cited. To view a copy of the license, visit http://creativecommons.org/licenses/by/3.0/

www.cjgh.org 